\title{
Stress Induced Degradation Modes in CIGS Mini-Modules
}

Conference Paper NREL/CP-520-43302

May 2008

\section{Preprint}

M.D. Kempe and K.M. Terwilliger

National Renewable Energy Laboratory

D. Tarrant

Shell Solar

Presented at the 33rd IEEE Photovoltaic Specialists Conference San Diego, California

May 11-16, 2008
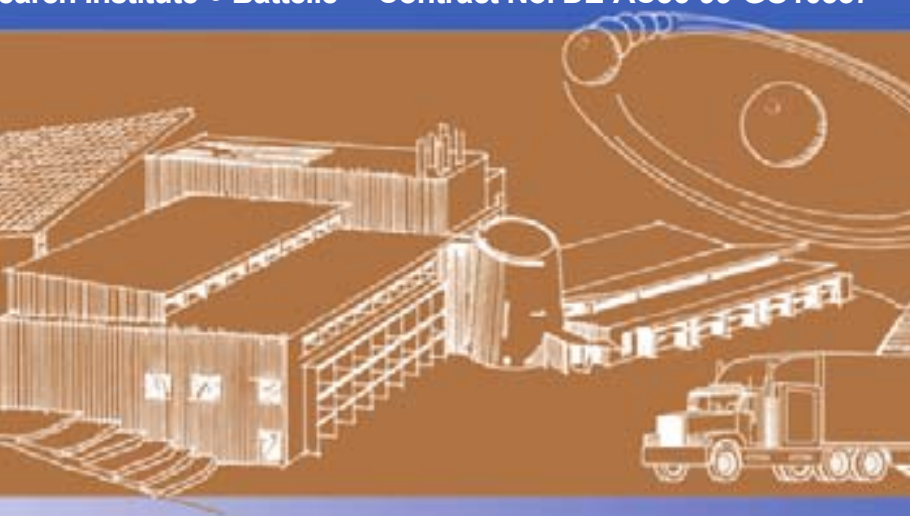


\section{NOTICE}

The submitted manuscript has been offered by an employee of the Midwest Research Institute (MRI), a contractor of the US Government under Contract No. DE-AC36-99G010337. Accordingly, the US Government and MRI retain a nonexclusive royalty-free license to publish or reproduce the published form of this contribution, or allow others to do so, for US Government purposes.

This report was prepared as an account of work sponsored by an agency of the United States government. Neither the United States government nor any agency thereof, nor any of their employees, makes any warranty, express or implied, or assumes any legal liability or responsibility for the accuracy, completeness, or usefulness of any information, apparatus, product, or process disclosed, or represents that its use would not infringe privately owned rights. Reference herein to any specific commercial product, process, or service by trade name, trademark, manufacturer, or otherwise does not necessarily constitute or imply its endorsement, recommendation, or favoring by the United States government or any agency thereof. The views and opinions of authors expressed herein do not necessarily state or reflect those of the United States government or any agency thereof.

Available electronically at http://www.osti.gov/bridge

Available for a processing fee to U.S. Department of Energy and its contractors, in paper, from:

U.S. Department of Energy

Office of Scientific and Technical Information

P.O. Box 62

Oak Ridge, TN 37831-0062

phone: 865.576 .8401

fax: 865.576 .5728

email: mailto:reports@adonis.osti.gov

Available for sale to the public, in paper, from:

U.S. Department of Commerce

National Technical Information Service

5285 Port Royal Road

Springfield, VA 22161

phone: 800.553 .6847

fax: 703.605.6900

email: orders@ntis.fedworld.gov

online ordering: http://www.ntis.gov/ordering.htm 


\title{
STRESS INDUCED DEGRADATION MODES IN CIGS MINI-MODULES
}

\author{
M. D. Kempe ${ }^{1}$, K. M. Terwilliger ${ }^{1}$, and D. Tarrant ${ }^{2}$. \\ ${ }^{1}$ National Renewable Energy Laboratory (NREL), 1617 Cole Boulevard, Golden, CO 80401 \\ 2 Shell Solar
}

\begin{abstract}
The stability of monolithically integrated copper (indium, gallium) (selenium, sulfur) (CIGS) based thin film solar cells on glass were evaluated as a function of highly accelerated stress testing. Mini-modules exposed to high humidity $\left(85^{\circ} \mathrm{C}\right.$ and $\left.85 \% \mathrm{RH}\right)$ had a dominant failure mechanism involving increased resistance in the $\mathrm{ZnO}: \mathrm{Al}$ transparent conducting oxide. Under Dry heat $\left(85^{\circ} \mathrm{C}\right.$ and $0 \% \mathrm{RH}$ ) performance loss was much slower and involved the weakening of diodes lowering $V_{o c}$ and loss of fill factor. These mini-modules were encapsulated using either ethylene vinyl-acetate (EVA) or a Silicone. It was found that encapsulation with EVA led to greater increases in series resistance. These experiments point to the importance of module packaging, transparent conducting oxide stability and cell integration in constructing durable CIGS modules.
\end{abstract}

\section{INTRODUCTION}

Thin film photovoltaic (PV) materials show great potential for reducing the cost of solar energy making it more broadly competitive with fossil fuels. These materials are constructed using layers only a few microns thick which greatly reduces the materials cost relative to wafer based crystalline silicon devices that are hundreds of microns thick.

CIGS based devices in particular show great promise with record small area efficiencies currently at $19.9 \%$ [1]. However, the small distances involved with thin films also makes the possibility of diffusion of contaminants from within the layers a greater threat. Because these materials are thin films the impact of small amounts of corrosion are more likely to cause larger performance losses.

Modules are encapsulated in polymeric materials to provide mechanical support and to help protect against the corrosive influence of atmospheric moisture and other contaminants. This study was undertaken to evaluate the effects of the choice of packaging materials, laminating conditions, and moisture ingress on long term stability.

\section{EXPERIMENTAL}

Shell Solar constructed 36, $15.2 \mathrm{~cm} \mathrm{X} 15.2 \mathrm{~cm}$ minimodules from their production CIGS on glass circuit plates and contacted them using their standard methods. These modules had an active area of $172 \mathrm{~cm}^{2}$ and consisted of 17 monolithically interconnected cells. These modules had Initial average cell parameters of: $V_{o c}=0.538 \mathrm{~V}$, $J_{s c}=32.8 \mathrm{~mA} / \mathrm{cm}^{2}, F F=65.7 \%$, and $\eta=11.59 \%$.

These mini-modules were laminated using either EVA or a room temperature curing silicone (GE RTV615). Lamination with EVA was accomplished by heating the samples up to $145^{\circ} \mathrm{C}$ for $8 \mathrm{~min}$. Lamination with GE RTV615 included the use of Dow Corning 1200 primer to ensure good adhesion. The front-sheet was made of either glass or Tefzel ${ }^{\mathrm{TM}}$. Samples were thus encapsulated with 4 different constructions with 7 to 9 replicates each.

After encapsulation, the samples were further divided into subgroups and exposed to a stress temperature of $85^{\circ} \mathrm{C}$ at either $0 \% \mathrm{RH}$ or $85 \% \mathrm{RH}$ for up to $8770 \mathrm{~h}$. Dry conditions were obtained by running a small flow of compressed air, with a dew point of $-40^{\circ} \mathrm{C}$, through an oven held at $85^{\circ} \mathrm{C}$. Damp heat, $85^{\circ} \mathrm{C}$ and $85 \% \mathrm{RH}$, was obtained in a Blue $M$ environmental chamber. Dry conditions were used to simulate the effect of perfectly functioning edge seals which are desired for production modules to pass damp heat tests.

Samples were light soaked outside in full sun for 2 hours prior to IV measurement to help minimize the effects of transient performance losses [2, 3]. IV measurements were performed on an XT-10 solar simulator using a well characterized and packaged mini-module as a reference cell for calibration. Custom software was made using Visual Basic 6.0 to assemble the IV measurements, calculate cell parameters, and organizing the results in a FileMaker Pro Database. From this the statistical software JMP IN was used to analyze the data. Changes in device parameters were calculated based on the performance after encapsulation.

IR images were taken using an Indigo Systems, Merlin $^{\mathrm{TM}}$ Mid, InSb middle wavelength IR camera using the IRVista software. Images were constructed by subtracting the pixel intensity for photos taken before and after application of a current.

\section{RESULTS}


Samples exposed to $85^{\circ} \mathrm{C}$ and $85 \% \mathrm{RH}$ quickly degraded by a mechanism involving large increases in resistance in the $\mathrm{ZnO}$ film and some loss in open circuit voltage $\left(V_{o c}\right)$ (see Fig.1). This drop in the $V_{o c}$ indicates some damage to the absorber layer has taken place.

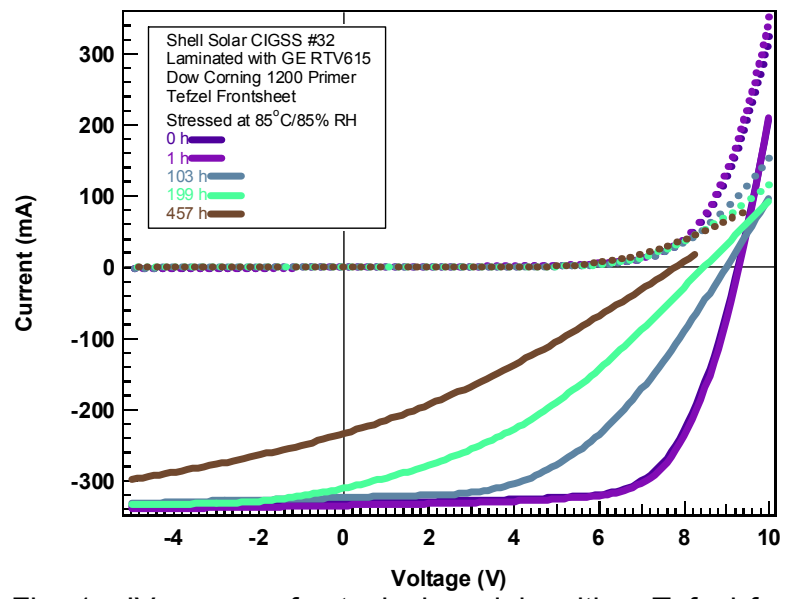

Fig. 1. IV curves of a typical module with a Tefzel frontsheet as a function of exposure $85^{\circ} \mathrm{C}$ and $85 \% \mathrm{RH}$.

Modules laminated using an impermeable glass frontsheet had slower degradation rates than those with a Tefzel front sheet (see Fig. 2). This result was expected as EVA and silicones are known to have very high diffusivities for water $[4,6]$. Over the time of this experiment one would expect moisture to penetrate the center of the mini-module package even with a glass frontsheet.

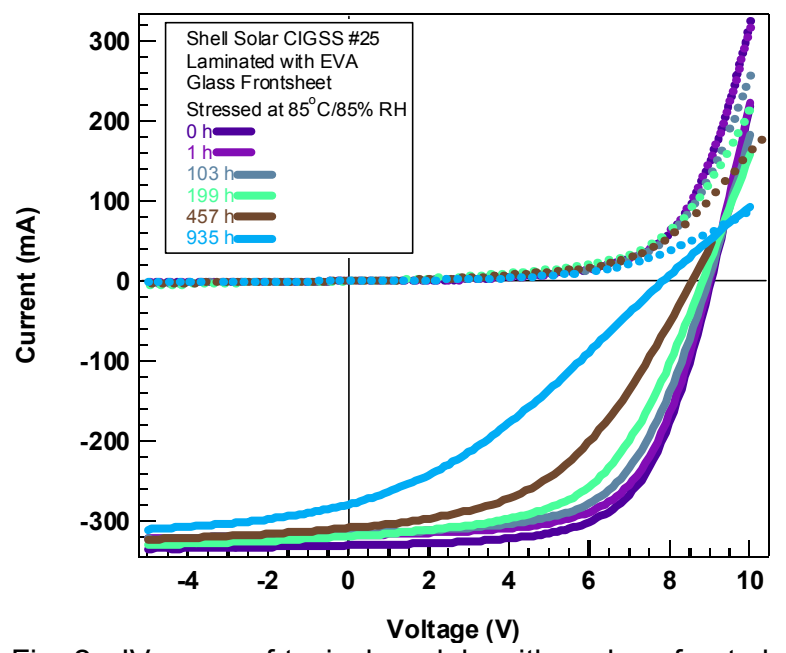

Fig. 2. IV curve of typical module with a glass front-sheet after exposure to $85^{\circ} \mathrm{C}$ and $85 \% \mathrm{RH}$.

The change in series resistance was confirmed by infrared imaging under an applied bias (see Fig. 3). Here the heating is strongest on the side of the cell adjacent to the $\mathrm{P} 1$ scribe. It is not the ohmic losses in the $\mathrm{ZnO}$ layer that are primarily responsible for the heating. As current crosses the cell in the $\mathrm{ZnO}$ layer its voltage drops whereas the voltage in the Mo backcontact remains more constant because of a relatively higher conductivity. This has a net result of producing a reduction in voltage drop across the cell as one moves away from the P1 scribe. Because of the strong current voltage relationship of a diode, this small voltage drop change creates a much larger change in current causing current crowding adjacent to the scribe where current enters the $\mathrm{ZnO}$ layer (see Fig 4). If instead the Mo layer was much more resistive than the $\mathrm{ZnO}$ layer, the current crowding would be on the opposite side of the cell near the P3 scribe.

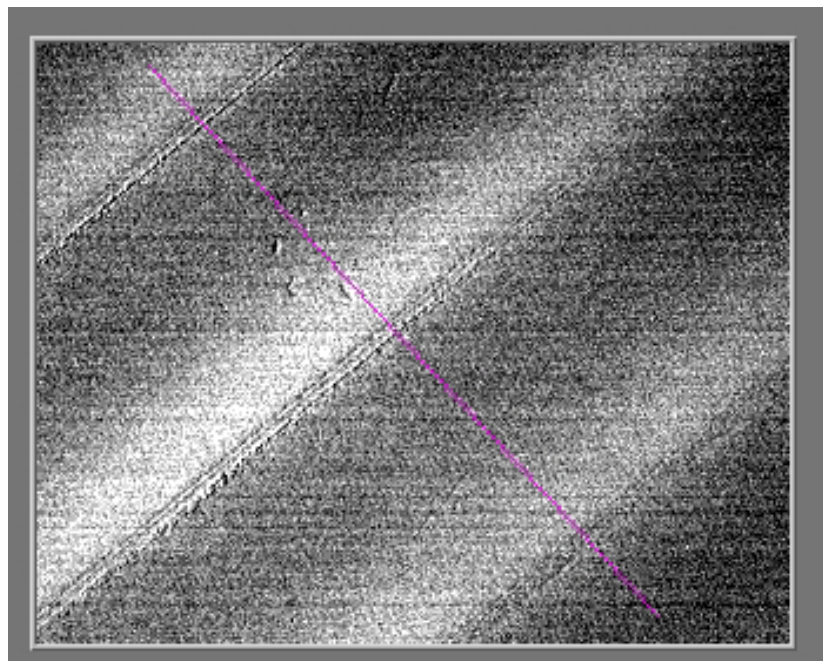

Fig. 3. Close-up infrared image of a Silicone/Tefzel encapsulated mini-module after exposure to $457 \mathrm{hrs}$ of $85^{\circ} \mathrm{C}$ and $85 \% \mathrm{RH}$. This image shows the change in temperature after the application of $81 \mathrm{~mA}$ at $9.5 \mathrm{~V}$ in forward bias for 10 s with no illumination.

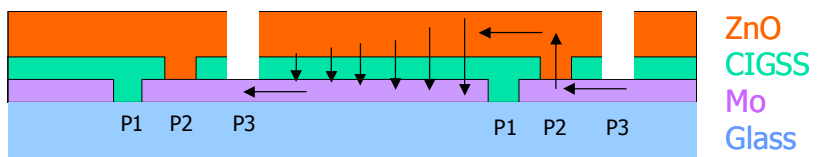

Fig. 4. Schematic of current flow through a cell with high resistance $\mathrm{ZnO}$.

The effects of exposure to dry heat produced a much slower degradation allowing stress testing for a longer period of $8770 \mathrm{~h}$ (see Figs. 5 and 6). A two-way ANOVA (see Table 1) indicates that the choice of encapsulant affected the light series resistance $\left(R_{S}\right.$, as inferred from the inverse slope at $\left.V_{o c}\right)$, the fill factor and the efficiency. Here EVA produced less desirable effects for these three factors. However, more experiments must be performed to determine if either the heat of lamination for EVA, or the use of a primer in the Silicone was a factor in this. The absence of any statistical significance in the cross terms indicates that the use of a glass front-sheet to partially trap acetic acid was not a significant factor in the degradation mechanisms.

Samples exposed to dry heat $\left(85^{\circ} \mathrm{C}\right.$ and $\left.0 \% \mathrm{RH}\right)$ also experienced losses in $V_{o c}$ (see Fig. 7). However, changes in $J_{s c}$ (see Fig. 8) and light shunt resistance $\left(R_{\text {sh,light }}\right)$ as 
inferred by the inverse slope at $J_{s c}$ (see Fig. 9) were statistically insignificant. Both $J_{s c}$ and $R_{s h \text {,light changes }}$ were not shown to be dependent on the encapsulant or the front-sheet used (see Table 1). However, the module parameters $F F, R_{s}$, and $\eta$ (see Figs. 10, 11, and 12) all showed better performance for modules laminated using a silicone rather than an EVA encapsulant.

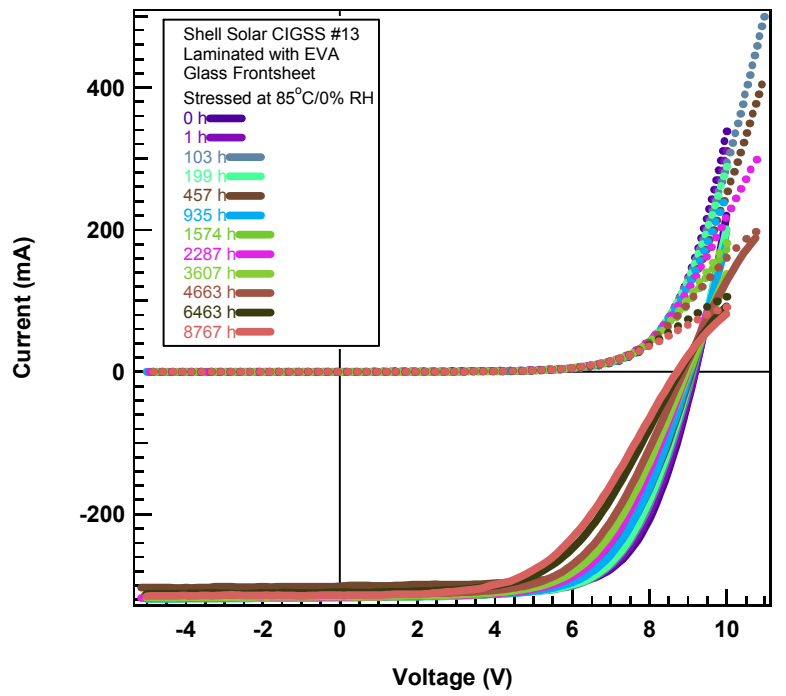

Fig. 5. Typical IV traces for a EVA/Glass encapsulated mini-module exposed to $85^{\circ} \mathrm{C}$ and $0 \% \mathrm{RH}$.

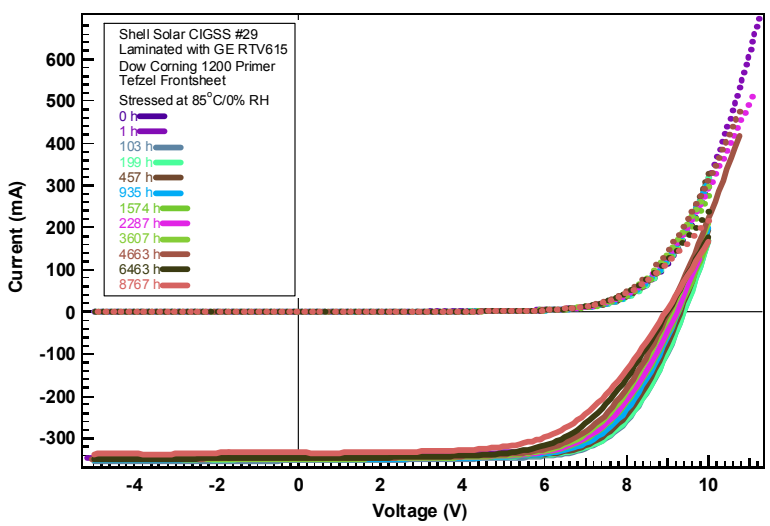

Fig. 6. Typical IV traces for a silicone/Tefzel encapsulated mini-module exposed to $85^{\circ} \mathrm{C}$ and $0 \% \mathrm{RH}$.

\begin{tabular}{|c|c|c|c|c|}
\hline \multicolumn{2}{|c|}{ Treatment } & Front-sheet & Encapsulant & $\begin{array}{c}\text { Encapsulant } \\
\text { Front-Sheet }\end{array}$ \\
\hline \multirow{2}{*}{$\Delta V_{\text {oc }}$} & F Ratio & 0.005 & 0.55 & 0.14 \\
\cline { 2 - 5 } & Probability & 0.94 & 0.47 & 0.72 \\
\hline \multirow{3}{*}{$\Delta J_{\text {sc }}$} & F Ratio & 0.40 & 0.080 & 1.15 \\
\cline { 2 - 5 } & Probability & 0.54 & 0.78 & 0.3 \\
\hline \multirow{2}{*}{$\Delta F F$} & F Ratio & 0.015 & 13.5 & 0.52 \\
\cline { 2 - 5 } & Probability & 0.91 & 0.0036 & 0.49 \\
\hline \multirow{2}{*}{$\Delta$ Efficiency } & F Ratio & 0.16 & 6.66 & 0.36 \\
\cline { 2 - 5 } & Probability & 0.70 & 0.026 & 0.56 \\
\hline \multirow{2}{*}{$\Delta R_{\text {sh,light }}$} & F Ratio & 1.6 & 0.19 & 0.0021 \\
\cline { 2 - 5 } & Probability & 0.23 & 0.67 & 0.96 \\
\hline \multirow{2}{*}{$\Delta R_{\text {s,light }}$} & F Ratio & 0.0012 & 8.3 & 0.77 \\
\cline { 2 - 5 } & Probability & 0.97 & 0.0149 & 0.40 \\
\hline \multirow{2}{*}{$\Delta R_{\text {sh,dark }}$} & F Ratio & 0.27 & 3.16 & 0.047 \\
\cline { 2 - 5 } & Probability & 0.62 & 0.10 & 0.83 \\
\hline
\end{tabular}

Table 1. Results of two factor ANOVA for samples exposed to $8770 \mathrm{~h}$ of $85^{\circ} \mathrm{C}$ and $0 \% \mathrm{RH}$. The " $\mathrm{F}$ ratio" is the ratio of the uncertainty between treatments to the sample set uncertainty. "Probability" is the chance of getting this $F$ ratio if the two treatments were actually equivalent. i.e. a large $F$ produces a small probability of error, indicating high confidence that the observed effects of the treatments are real. The last row, "Encapsulant*Front-sheet", indicates the probability that interactions between treatments significantly affect the results.

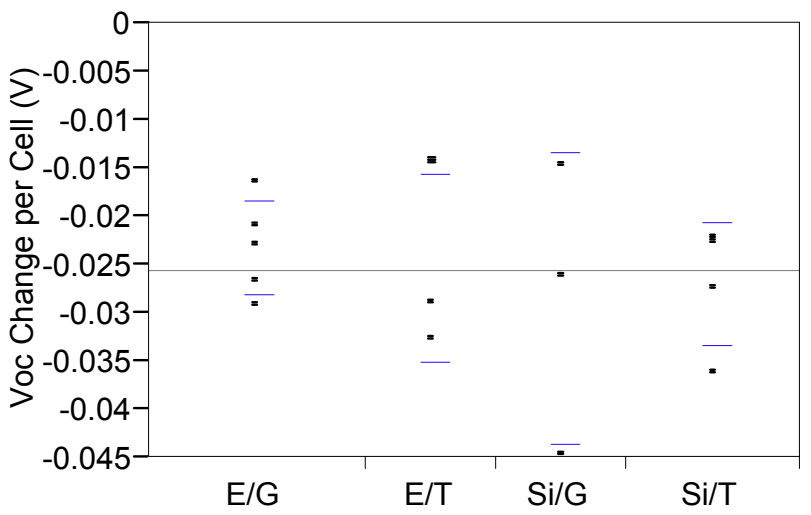

Fig. 7. Open circuit voltage change after $8770 \mathrm{~h}$ of $85^{\circ} \mathrm{C}$ and $0 \% \mathrm{RH}$ exposure. $\mathrm{E}=\mathrm{EVA}, \mathrm{Si}=$ Silicone, T=Tefzel, $\mathrm{G}=\mathrm{Glass}$. For this and all similar plots, the horizontal lines for each data set correspond to the 95\% confidence interval for the magnitude of the changes. The large horizontal line spanning the plots is the grand mean for the data set. 


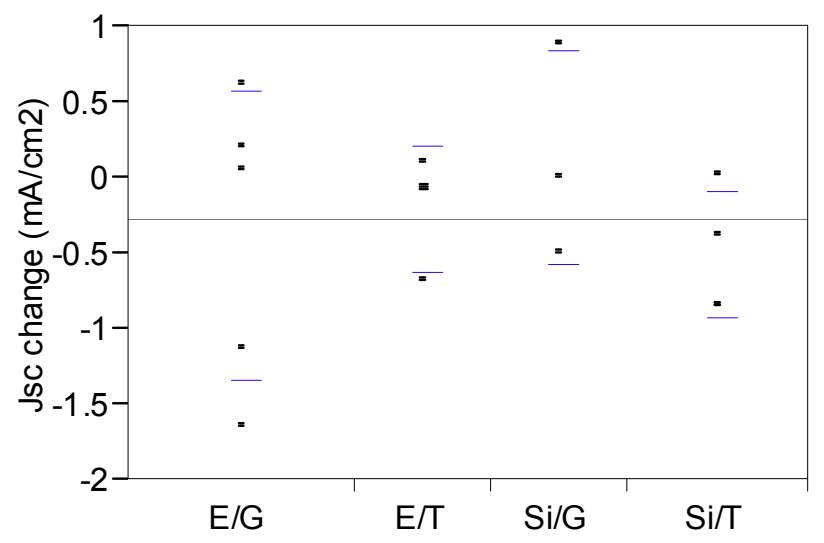

Fig. 8. Cell short circuit current change $\left(\mathrm{mA} / \mathrm{cm}^{2}\right)$ after $8770 \mathrm{~h}$ of $85^{\circ} \mathrm{C}$ and $0 \% \mathrm{RH}$ exposure. $\mathrm{E}=\mathrm{EVA}$, $\mathrm{Si}=$ Silicone, $\mathrm{T}=$ Tefzel, $\mathrm{G}=$ Glass.

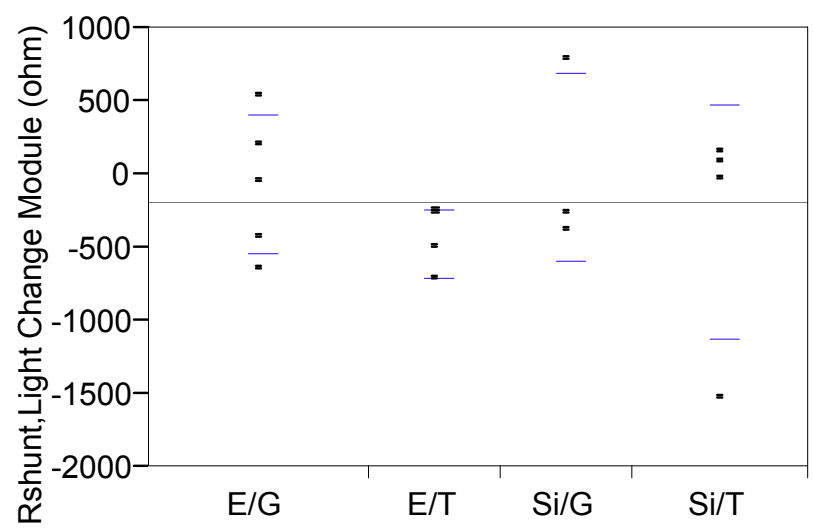

Fig. 9. Shunt resistance change $(\Omega)$ inferred from the inverse slope at $J_{s c}$ under 1 sun illumination after $8770 \mathrm{~h}$ of $85^{\circ} \mathrm{C}$ and $0 \% \mathrm{RH}$ exposure. $\mathrm{E}=\mathrm{EVA}$, Si=Silicone, $\mathrm{T}=$ Tefzel, $\mathrm{G}=\mathrm{Glass}$.

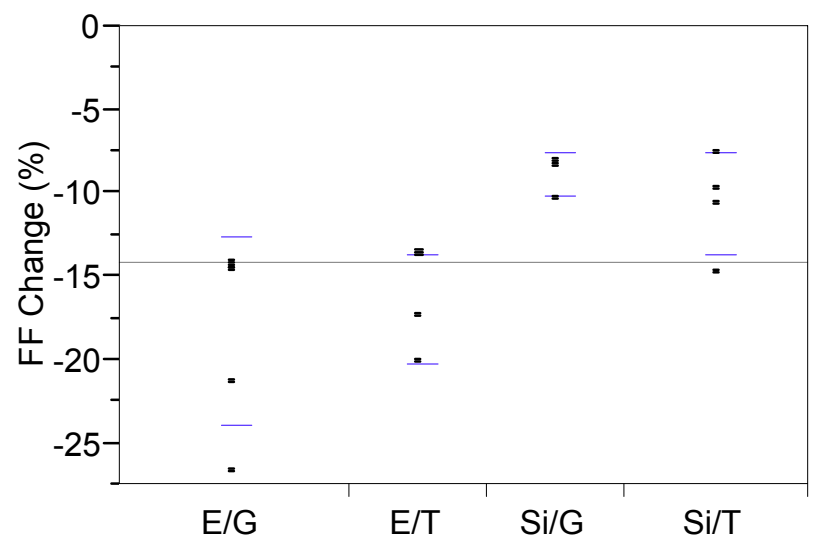

Fig. 10. Fill factor change after $8770 \mathrm{~h}$ of $85^{\circ} \mathrm{C}$ and $0 \%$ $\mathrm{RH}$ exposure. $\mathrm{E}=\mathrm{EVA}, \mathrm{Si}=$ Silicone, $\mathrm{T}=$ Tefzel, $\mathrm{G}=\mathrm{Glass}$.

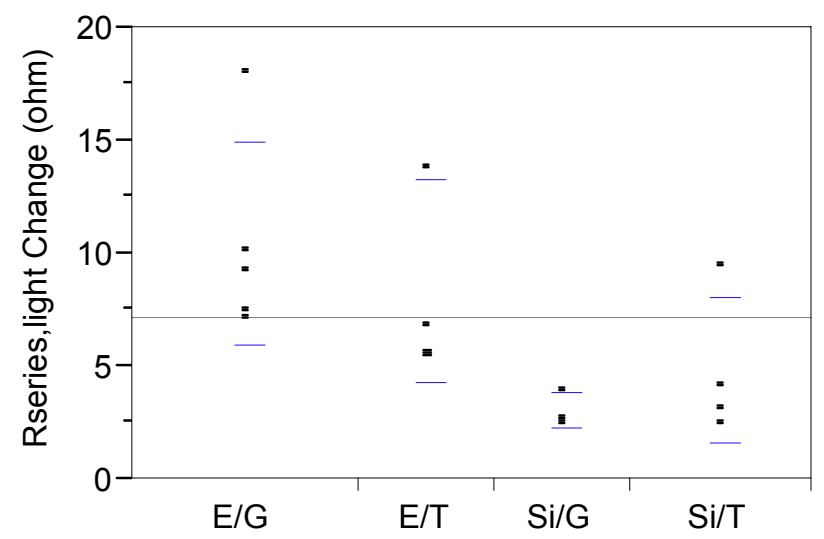

Fig. 11. Series resistance change $(\Omega)$ after $8770 \mathrm{~h}$ of $85^{\circ} \mathrm{C}$ and $0 \% \mathrm{RH}$ exposure. Estimated based on the inverse slope of the IV curve at $V_{o c}$ under 1 sun illumination. $E=E V A, S i=S i l i c o n e, T=T e f z e l, G=G l a s s$.

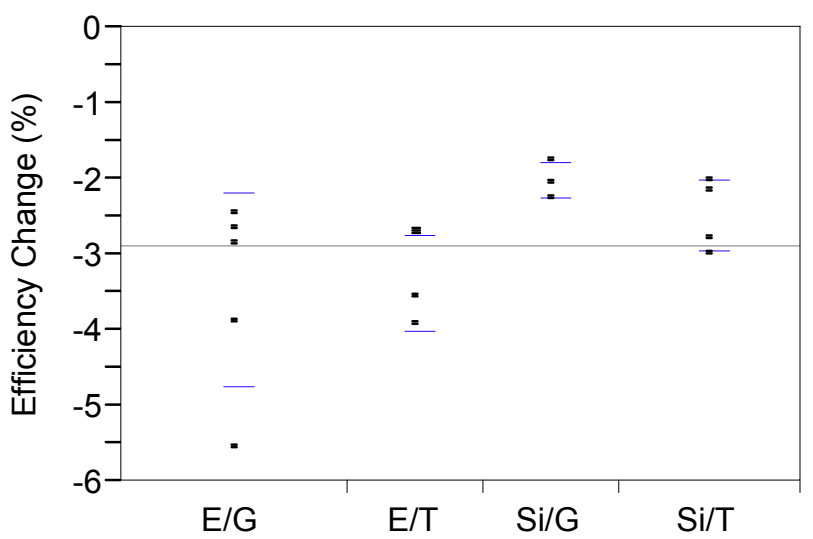

Fig. 12. Absolute efficiency change after $8770 \mathrm{~h}$ of $85^{\circ} \mathrm{C}$ and $0 \% \mathrm{RH}$ exposure. $\mathrm{E}=\mathrm{EVA}, \mathrm{Si}=\mathrm{Silicone}, \mathrm{T}=$ Tefzel, $\mathrm{G}=\mathrm{Glass}$.

At $8770 \mathrm{~h}$ of $85^{\circ} \mathrm{C}$ and $0 \% \mathrm{RH}, \mathrm{IR}$ images are starting to show current crowding near the P1 scribe (see Fig. 13). This change was of a much smaller magnitude as compared to cells stressed in $85 \% \mathrm{RH}$ (see Fig. 3) and was not easily apparent in all modules. This verifies that the change in $R_{s}$ (inferred from the inverse slope of the $\mathrm{J}$ $V$ curve) is not due solely to changes in other cell properties such as the diode quality factor [5] but that it has a component attributable to $\mathrm{ZnO}$ resistance changes.

IR imaging was performed after application of both a forward and a reverse bias. Under forward bias hot spots can correspond to shunt paths or to weak diodes but under reverse bias only shunts show up as hot spots. Examination of IR images taken during the course of the experiment revealed more weak diodes than it did shunt paths. However, because of the lower current levels under reverse bias it is possible that this technique was less able to detect them. During stress testing, the number of weak diodes only increased slightly. There was some change in the relative intensity of the weak diodes but due to the qualitative nature of this analysis technique 
we were not able to determine with confidence if specific areas were weakened.

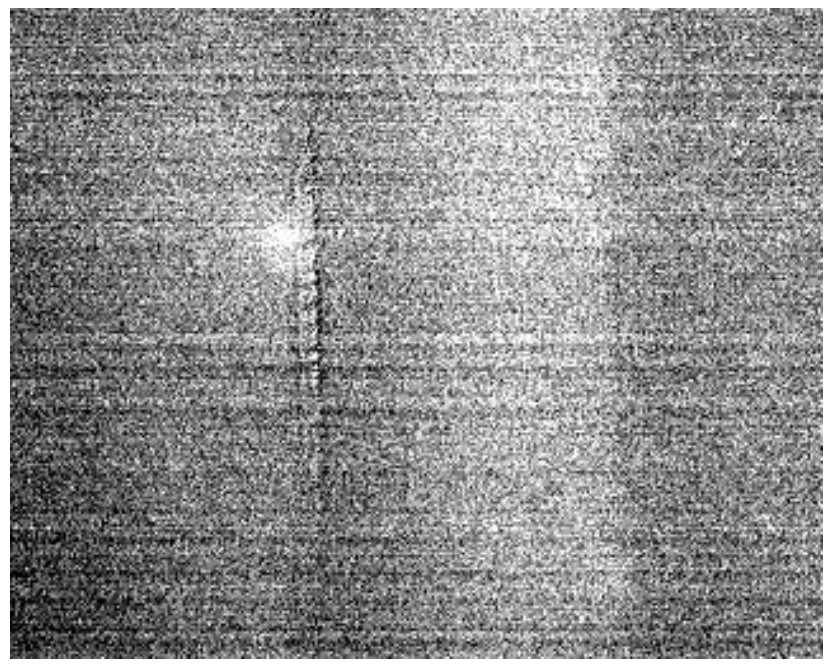

Fig. 13 Module \#15 after $8770 \mathrm{~h} 85^{\circ} \mathrm{C}$ and $0 \% \mathrm{RH}$. Under forward bias of $9.5 \mathrm{~V}$ and $31 \mathrm{~mA}$ for $15 \mathrm{~s}$. Constructed with EVA and a Tefzel front-sheet.

Because a Tefzel front-sheet was used in some modules, good IR radiation transmission was obtained allowing us to identify the exact location of the weak diodes (see Fig. 14). The majority of the weak diodes are located near the P1 scribe lines or along the cell edges where materials have been removed down to the glass layer (see Fig. 15). Furthermore the weak diodes located in the middle of the cells did not generally heat up as much as the other weak diodes. This indicates that the process of producing scribes and defining cells is very important for creating a CIGS module.

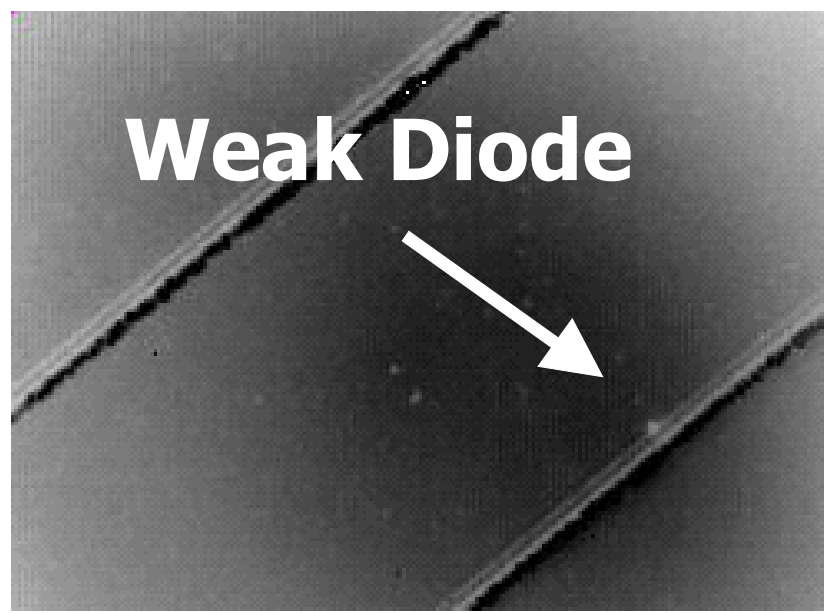

Fig. 14. IR image of a weak diode. The cell pictured was illuminated using a flashlight with the light restricted to shine only outside of the image area. This weak diode also shined brightly under forward bias.

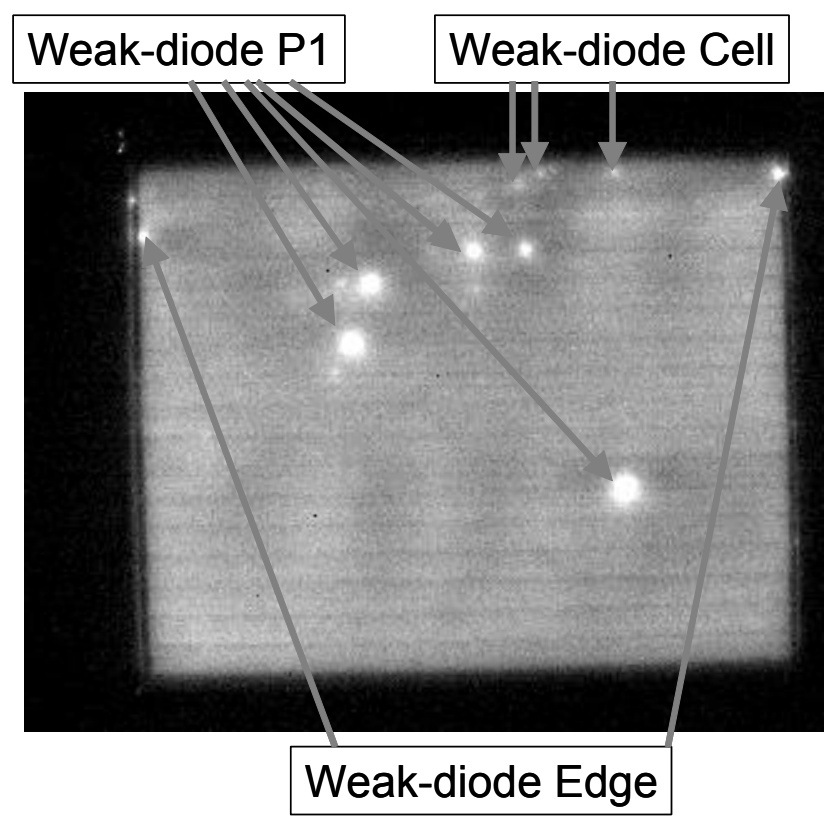

Fig. 15. IR image of a typical silicone/Tefzel encapsulated mini-module after $2290 \mathrm{~h} 80^{\circ} \mathrm{C}$ and $0 \% \mathrm{RH}$. This image shows the change in temperature after the application of $153 \mathrm{~mA}$ at $9.3 \mathrm{~V}$ in forward bias for $20 \mathrm{~s}$ with no illumination.

Correlation coefficients were calculated comparing the variability between changes in various parameters. This yields different results than one would get if the correlation coefficients between the actual parameters was calculated. Correlation coefficients concern the deviations around the means of a sample set. With the actual parameters there would be a residual component from the onset of the experiments. Because the changes in parameters were calculated based on conditions after lamination, the correlation coefficients for the actual parameters would include information about the choice of front sheet which would affect $J_{s c}$ in particular.

After $8770 \mathrm{~h}$ of dry heat, EVA samples showed a strong correlation between changes in $F F$, changes in $J_{S c}$ and in changes in efficiency $\left[\operatorname{Corr}\left(F F, J_{S c}\right)_{\mathrm{EVA}}=0.932\right.$, $\operatorname{Corr}(F F, \eta)_{\mathrm{EVA}}=0.981$, and $\left.\operatorname{Corr}\left(J_{s c}, \eta\right)_{\mathrm{EVA}}=0.914\right]$. Here it should be noted that there was not a statistically significant change in $J_{s c}$ for EVA (see Fig. 8). The presence of a strong correlation indicates that samples with a slightly improved $J_{s c}$ had smaller changes in FF and conversely samples with $J_{s c}$ losses had greater $F F$ losses. This indicates a high probability that a single mechanism is responsible for most of the variability in changes in $J_{s c}$ and changes in FF within the EVA sample set.

For the silicone samples, $8770 \mathrm{~h}$ of dry heat produced only moderately statistically significant correlations between changes in efficiency and changes in $F F$ or changes in $J_{s c} \quad\left[\operatorname{Corr}(F F, \eta)_{\text {Silicone }}=0.67\right.$, and $\left.\operatorname{Corr}\left(J_{s c}, \eta\right)_{\text {silicone }}=0.64\right]$. Furthermore, as opposed to EVA, the correlation between changes in fill factor and changes in $J_{s c}$ with silicones were completely insignificant [Corr $\left(F F, J_{s c}\right)_{\text {Silicone }}=-0.094$ ]. The lack of significant 
correlation in silicones as opposed to strong correlation in with EVA indicates that different and/or more mechanisms are causing degradation in EVA. Because the EVA samples had both stronger correlations and greater changes in $F F$ (see Fig. 10), it is probable that there exists a dominant FF degradation pathway in EVA that also affects $J_{s c}$ but that is relatively insignificant for the silicone encapsulated cells.

The correlation between changes in FF and changes in series resistance losses were moderate for EVA and strong for silicone [Corr $\left(F F, R_{S}\right)_{\mathrm{EVA}}=-0.50$, $\operatorname{Corr}\left(F F, R_{s}\right)$ silicone $\left.=-0.9434\right]$ Furthermore, the losses related to $F F$ and $R_{s}$ are larger (see Figs. 10 and 11) for EVA. These facts indicate that there are a larger number of statistically significant degradation pathways leading to $F F$ and $R_{s}$ losses in EVA than in silicone. It is the presence multiple independent degradation mechanisms that causes this correlation to be insignificant in EVA. I.e. in Silicone one dominant degradation pathway causes both $F F$ and $R_{s}$ losses whereas in EVA there are two or more significant and independent pathways affecting changes in FF and changes in $R_{S}$.

Because EVA had such strong correlations between changes in $F F$, changes in $J_{s c}$ and changes in efficiency, the extra degradation pathway, relative to silicones, affecting the correlation between $F F$ and $R_{s}$ probably only affects $R_{s}$. This may also be linked to the observation that the EVA encapsulated cells tended to have stronger inflection in the I-V curve which could also account for the larger changes in $R_{s}$ inferred from the inverse slope of the I-V curve (see Figs. 5 and 6 as representative plots). Other than those mentioned here, no other strongly statistically significant correlations were found in the changes in device parameters.

The greater degradation in EVA relative to silicones may be attributable to either the higher polarity of EVA, to the production of acetic acid by-products [6], to the use of heat during lamination, or to the use of a primer with the silicone materials. More experimentation is necessary to evaluate the sources of this enhanced degradation.

\section{CONCLUSIONS}

Exposure to $85^{\circ} \mathrm{C}$ and $85 \% \mathrm{RH}$ was found to dramatically affect cells by changing the resistance of the $\mathrm{ZnO}$ film along with some changes to $V_{o c}$. Upon exposure to $8770 \mathrm{~h}$ of $85^{\circ} \mathrm{C}$ and $0 \% \mathrm{RH}$, samples encapsulated using EVA experienced a statistically significant greater loss in efficiency than did samples encapsulated with silicone. EVA samples experienced greater losses in FF and increases in series resistance. IR images confirm that some of the changes in series resistance (inferred from the inverse slope if the IV curve) were due to changes in the $\mathrm{ZnO}$ resistivity rather then cell parameters such as diode quality. Changes in shunting were statistically insignificant. These loss mechanisms in dry heat result in the lowering of $V_{o c}$ for all samples regardless of the encapsulant. IR imaging indicated only small increases in the number of weak diodes.
This study demonstrates that the method of encapsulation can affect the long term stability of CIGS modules principally through interactions with the $\mathrm{ZnO}$. The effect of packaging materials on $J_{s c}$ and $V_{o c}$ stability was not significant. Improvements in the deposition of the $\mathrm{ZnO}$ or substitution with other conductors, such as indium tin oxide, may improve the stability of CIGS based devices.

\section{ACKNOWLEDGEMENTS}

The authors would like to thank Tom McMahon for helping with the infrared imaging and David Albin for help with computer code. This work was carried out under U.S. Department of Energy contract number DE-AC36$99 \mathrm{G} 010337$.

\section{REFERENCES}

[1] I. Repins, M. A. Contreras, B. Egaas, C. DeHart, J. Scharf, C. L. Perkins, B. To, R. Noufi, "19.9\%-efficient $\mathrm{ZnO} / \mathrm{CdS} / \mathrm{CulnGaSe} 2$ solar cell with $81.2 \%$ fill factor", Progress in Photovoltaics: Research and Applications 16, 235 (2008).

[2] D. E. Tarrant and R. R. Gay, "Thin-Film Photovoltaic Partnership - CIS-Based Thin Film PV Technology", Final Technical Report, NREL/SR-520-27148, October (1999).

[3]. Johnson, J. Sites, K. Ramanathan, L. Olsen, D. Tarrant, "Effects of Buffer Layers on SSI CIGSS-Absorber Transient IV and C-V Behavior", 28 ${ }^{\text {th }}$ IEEE PVSC Conference, Anchorage Alaska, (2000).

[4] M.D. Kempe, "Modeling of Rates of Moisture Ingress into Photovoltaic Modules", Solar Energy Materials and Solar Cells, 90 (2006) 2720-2738.

[5] J. R. Sites, P. H. Mauk, "Diode Quality Factor Determination for Thin-Film Solar Cells", Solar Cells, 27, 411-417 (1989).

[6] M.D. Kempe, G.J. Joregensen, K.M. Terwilliger, T.J. McMahon, C.E. Kennedy, T.T. Borek, "Acetic Acid Production and Glass Transitions Concerns with EthyleneVinyl Acetate used in Photovoltaic Devices", Solar Energy Materials \& Solar Cells, 91, 315-329 (2007). 


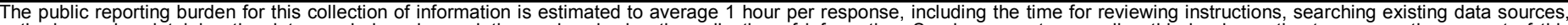

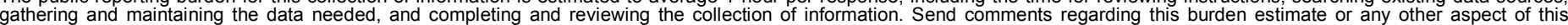

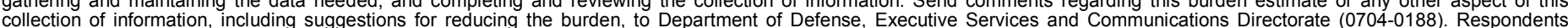

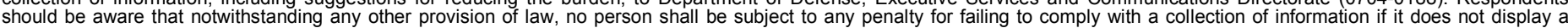

should be aware that notwithstandin

PLEASE DO NOT RETURN YOUR FORM TO THE ABOVE ORGANIZATION.

\section{REPORT DATE (DD-MM-YYYY) \\ May 2008 \\ 2. REPORT TYPE \\ Conference Paper}

4. TITLE AND SUBTITLE

Stress Induced Degradation Modes in CIGS Mini-Modules: Preprint

6. AUTHOR(S)

M.D. Kempe, K.M. Terwilliger, and D. Tarrant
3. DATES COVERED (From - To)

11-16 May 2008

5a. CONTRACT NUMBER

DE-AC36-99-G010337

5b. GRANT NUMBER

5c. PROGRAM ELEMENT NUMBER

5d. PROJECT NUMBER

NREL/CP-520-43302

5e. TASK NUMBER

PVB76701

5f. WORK UNIT NUMBER

\section{PERFORMING ORGANIZATION NAME(S) AND ADDRESS(ES)}

National Renewable Energy Laboratory, 1617 Cole Blvd., Golden, CO 80401-3393

Shell Solar
8. PERFORMING ORGANIZATION REPORT NUMBER

NREL/CP-520-43302

9. SPONSORING/MONITORING AGENCY NAME(S) AND ADDRESS(ES)

10. SPONSOR/MONITOR'S ACRONYM(S) NREL

11. SPONSORING/MONITORING AGENCY REPORT NUMBER

12. DISTRIBUTION AVAILABILITY STATEMENT

National Technical Information Service

U.S. Department of Commerce

5285 Port Royal Road

Springfield, VA 22161

\section{SUPPLEMENTARY NOTES}

14. ABSTRACT (Maximum 200 Words)

The stability of monolithically integrated copper (indium, gallium) (selenium, sulfur) (CIGS) based thin film solar cells on glass were evaluated as a function of highly accelerated stress testing. Mini-modules exposed to high humidity $\left(85^{\circ} \mathrm{C}\right.$ and $\left.85 \% \mathrm{RH}\right)$ had a dominant failure mechanism involving increased resistance in the $\mathrm{ZnO}$ :Al transparent conducting oxide. Under Dry heat $\left(85^{\circ} \mathrm{C}\right.$ and $\left.0 \% \mathrm{RH}\right)$ performance loss was much slower and involved the weakening of diodes lowering $V_{o c}$ and loss of fill factor. These mini-modules were encapsulated using either ethylene vinyl-acetate (EVA) or a Silicone. It was found that encapsulation with EVA led to greater losses in series resistance. These experiments point to the importance of module packaging, transparent conducting oxide stability and cell integration in constructing durable CIGS modules.

15. SUBJECT TERMS

PV; modules; monolithically integrated copper; thin film; solar cells; stress testing; transparent conducting oxide; diodes;

\begin{tabular}{|c|c|c|c|c|}
\hline \multicolumn{3}{|c|}{ 16. SECURITY CLASSIFICATION OF: } & \multirow{2}{*}{$\begin{array}{l}\text { 17. LIMITATION } \\
\text { OF ABSTRACT } \\
\text { UL }\end{array}$} & \multirow{2}{*}{$\begin{array}{ll}\text { 18. } & \text { NUMBER } \\
\text { OF PAGES }\end{array}$} \\
\hline $\begin{array}{l}\text { a. REPORT } \\
\text { Unclassified }\end{array}$ & $\begin{array}{l}\text { b. ABSTRACT } \\
\text { Unclassified }\end{array}$ & $\begin{array}{l}\text { c. THIS PAGE } \\
\text { Unclassified }\end{array}$ & & \\
\hline
\end{tabular}

19a. NAME OF RESPONSIBLE PERSON

19b. TELEPHONE NUMBER (Include area code) 